\title{
PENGEMBANGAN GAME ANDROID BERBANTUAN SOFTWARE CONSTRUCT 2 PADA MATERI POLA BILANGAN
}

\author{
DEVELOPING ANDROID GAMES WITH \\ CONSTRUCT 2 SOFTWARE ON NUMBER PATTERN
}

\author{
Untung Ali Miftahuddin', Hobri' ${ }^{2}$, Randi Pratama Murtikusuma ${ }^{3}$ \\ 1 Universitas Jember, ali.miftah@gmail.com \\ 2 Universitas Jember, hobri1973@gmail.com \\ 3 Universitas Jember, randi.popo@gmail.com
}

\begin{abstract}
ABSTRAK. Tujuan penelitian adalah untuk mendeskripsikan proses dan mengetahui hasil pengembangan media pembelajaran matematika berbasis game Android. Proses pengembangan menggunakan model Thiagarajan yang terdiri dari empat tahap. Tahap pendefinisian untuk menetapkan tujuan pembuatan media. Tahap perencanaan yaitu proses merancang media pembelajaran, sehingga dihasilkan draft 1 . Tahap pengembangan yaitu melakukan validasi serta uji coba dilakukan di SMPN 4 Jember. Tahap penyebaran dilaksanakan di seluruh kelas VIII SMP Negeri 4 Jember. Media pembelajaran matematika berbasis game android berbantuan software construct 2 pada pola bilangan telah memenuhi kriteria valid $(0,87)$, praktis $(86 \%)$, dan efektif $(90 \%)$.
\end{abstract}

Kata Kunci: Pengembangan, Construct 2, Game Android, Pola Bilangan

ABSTRACK. The purpose of the research is to describe the process and find out the results of the development of mathematics learning media based on Android games. The development process uses the Thiagarajan model which consists of four stages. The defining stage is to establish the purpose of making media. The planning stage is the process of designing instructional media, so a draft 1. The development stage is validated and a trial is conducted at SMPN 4

Jember. The deployment phase is carried out throughout the eighth grade of SMP Negeri 4 Jember. Mathematics learning media based on Android game assisted by software construct 2 on number patterns has met the valid criteria (0.87), practical $(86 \%)$, and effective $(90 \%)$.

Keywords: Development, Construct 2, Android Games, Number Patterns 


\section{PENDAHULUAN}

Pendidikan di Indonesia selalu mengalami perkembangan. Perkembangan tersebut dapat dilihat melalui adanya perubahanperubahan yang bertujuan untuk memenuhi tuntutan perkembangan dan peningkatan kualitas pendidikan. Menurut Soedjadi (2000), mendefinisikan pendidikan adalah usaha yang dilakukan agar peserta didik mencapai tujuan pendidikan. Dalam dunia pendidikan, matematika merupakan ilmu dasar yang mempunyai peran dalam berbagai disiplin ilmu dan perkembangan teknologi informasi serta komunikasi. Matematika merupakan suatu sarana berfikir untuk mengkaji sesuatu secara logis, kritis dan rasional serta sistematis serta melatih kemampuan siswa agar terbiasa dalam memecahkan suatu masalah yang ada disekitarnya (Sari, 2019). Matematika sebagai ilmu dasar berperan dalam mengembangkan cara berpikir logis, bersikap kritis dan bertindak nasional.

Pada jenjang Sekolah Menengah Pertama (SMP) salah satu pokok bahasan dalam matematika yang harus dipelajari dan dapat menggunakan teknologi multimedia adalah Pola Bilangan. Materi akan lebih mudah dipahami siswa jika penyampaian materi tersebut dikaitkan dalam kehidupan nyata dari lingkungan siswa tersebut. Agar proses belajar matematika terjadi, bahasa matematika setidaknya tidak disajikan dalam bentuk yang sudah final melainkan siswa dapat terlibat aktif di dalam menentukan konsep-konsep, struktur-struktur sampai kepada teorema atau rumus (Setiawani, Hobri, \& Wibowo, 2017)

Selama ini ada beberapa faktor yang mempengaruhi prestasi siswa. Diantaranya adalah penggunaan metode dan media pembelajaran matematika yang masih kurang bervariasi. Selain itu penggunaan media pembelajaran matematika di sekolah dirasa masih kurang optimal. Media pembelajaran adalah aplikasi multimedia yang digunakan dalam proses pembelajaran, dengan kata lain untuk menyalurkan pesan (pengetahuan, keterampilan dan sikap) serta dapat merangsang pilihan, perasaan, perhatian dan kemauan siswa sehingga secara sengaja proses belajar terjadi, bertujuan dan terkendali (Daryanto, 2010). Hal ini senada yang diungkap oleh (Asmin, 2003), bahwa beberapa guru matematika di Indonesia selama ini masih terbiasa mengajar dengan metode ceramah dan penyampaiannya cenderung monoton sehingga siswa cenderung pasif. Faktor lain yang mempengaruhi rendahnya hasil belajar siswa adalah kurangnya variasi metode yang digunakan saat pembelajaran (Ulfa, 2018).

Pada abad 21 sangat berbeda dari abad-abad sebelumnya dimana globalisasi, teknologi baru, dan pertumbuhan pengetahuan di masyarakat menuntut warga negara untuk lebih kreatif (Tirri, Cho, Ahn, \& Campbell, 2017). Dalam bidang pendidikan, perkembangan teknologi informasi dan komunikasi dimanfaatkan sebagai salah satu alat bantu atau media yang 
digunakan dalam proses belajar mengajar dimana juga dapat disebut media pembelajaran (Wahid, Fatahillah, \& Dafik, 2016). Salah satu media pembelajaran yang dapat dimaanfaatkan pendidik yaitu dengan memanfaatkan teknologi infomasi. Teknologi informasi mempengaruhi perkembangan media pembelajaran (Putriani, 2017). Salah satu tekonologi informasi yang dapat dimanfaatkan sebagai media pembelajaran yaitu handphone android. Dari berbagai fitur yang ada pada HP Android, fitur game salah satu yang paling digemari. (Mulyani, 2018) melakukan penelitian tentang dampak dari pemanfaatan aplikasi android dalam pembelajaran matematika materi bangun ruang sisi lengkung. Hasil yang didapatkan yaitu adanya peningkatan hasil belajar siswa dalam memahami materi bangun ruang sisi lengkung setelah menggunakan aplikasi android.

Game adalah salah satu media hiburan yang banyak diminati oleh berbagai kalangan dari anak kecil hingga orang dewasa. Fitur game merupakan fitur yang paling digemari, bukan hanya dapat menghilangkan kebosanan, namun juga memiliki tantangan tersendiri bagi pemainnya terutama para pelajar atau siswa dikala mereka merasa bosan dengan pelajaran di sekolah. Mereka beralasan bahwa game dapat dijadikan sebagai alat hiburan saat bosan dalam belajar. Game juga dapat dijadikan sebagai media pembelajaran yang memungkinkan siswa untuk lebih bersemangat mempeljari matematika. Matematika satu diantara sejumlah pelajaran yang dianggap sedikit diminati oleh anak-anak di Indonesia karena persepsi mereka beranggapan matematika itu sulit (Kevin, 2019). Salah satu permasalahan yang muncul saat siswa mempelajari matemtika yaitu kurang memahami konsep sebenarnya baik dari penyampaian gurunya maupun kurangnya penggunaan media (Khatimah, Johar, \& Taufik Fuandi Abidin, 2019). Terdapat perbedaan pencapaian kemampuan pemahaman matematis siswa antara siswa yang menggunakan media pembelajaran game dengan yang menggunakan pembelajaran konvensional (Idris, 2019).

Penelitian mengenai pengembangan media banyak diteliti oleh peneliti-peneliti sebelumnya. Penelitian tersebut dapat dijadikan sebagai rujukan atau penelitian yang relevan bagi peneliti selanjutnya. Berdasarkan uraian tersebut, diajukan penelitian dengan judul Pengembangan Media Pembelajaran Matematika Berbasis Game Android Berbantuan Software Consruct 2 Pada Pola Bilangan.

\section{METODE PENELITIAN}

Jenis penelitian ini adalah penelitian pengembangan (research and development), dengan tujuan untuk menghasilkan suatu produk tertentu yang akan diuji kevalidan, kepraktisan dan keefektifan. Menurut Borg dan Gall, penelitian pengembangan adalah suatu proses yang dipakai untuk mengembangkan dan memvalidasi produk pendidikan (Setyosari, 2013). Pada penelitian ini produk yang dikembangkan adalah media 
pembelajaran berupa permainan yang memuat materi serta soal-soal mengenai pola bilangan yang dikemas dalam bentuk game edukasi matematika dengan bantuan software Construct 2. Pelaksanaan uji coba penelitian diadakan di SMP Negeri 4 Jember di kelas VIII E dengan jumlah 30 siswa.

Model pengembangan yang digunakan adalah model Thiagarajan. Model Thiagarajan dikenal dengan model 4-D yang terdiri dari empat tahap. Tahap-tahap tersebut terdiri dari tahap pendefinisian ,tahap perancangan, tahap pengembangan dan tahap penyebaran. Tahap pengembangan media pembelajaran matematika berbasis game android berbantuan software construct 2 pada pola bilangan menggunakan model Thiagarajan yang terdiri dari empat tahap yaitu, yaitu sebagai berikut:

1) Tahap Pendefinisian, pada tahap ini menetapkan tujuan pembuatan media pembelajaran matematika berupa game android dengan berbantuan software Construct 2 .

- Analisis Awal-Akhir : mengkaji masalah yang terjadi dalam pengembangan media pembelajaran yaitu ketidaktertarikan siswa pada media pembelajaran yang digunakan saat kegiatan belajar mengajar

- Analisis Subjek : Kemajuan teknologi dan informasi berdampak pada karakter siswa SMPN 4 Jember

- Analisis Konsep : Materi yang digunakan dalam media pembelajaran matematika ini yaitu pola bilangan.

- Analisis Tugas: Tugas yang diberikan kepada siswa meliputi latihan soal sebagai pemantapan siswa terhadap pemahaman materi yang diajarkan, serta tes hasil belajar sebagai tolak ukur kemampuan siswa terhadap pemahaman materi yang diajarkan.

- Perumusan : Tujuan yang ingin dicapai dengan adanya media pembelajaran ini adalah menciptakan media pembelajaran yang dapat mempermudah proses pembelajaran, efisien, menyenangkan, mempermudah interaksi siswa dan guru serta dapat menarik minat belajar siswa.

2) Tahap Perencanaan, pada tahap ini merupakan proses merancang media pembelajaran, sehingga dihasilkan draft 1 (media pembelajaran yang belum valid)

- Pemilihan Media : Media pembelajaran yang dikembangkan dalam penelitian ini berupa aplikasi game edukasi android yang diberi nama GEMBIL (Game Edukasi Matematika materi Pola Bilangan) berdasarkan analisis siswa, analisis tugas dan analisis konsep pada tahap pendefinisian. Media pembelajaran yang dikerjakan oleh peneliti menggunakan algoritma logika untuk mendapatkan konsep game yang terdiri dari 6 level permainan, latihan pada game serta ujian secara tulis. 
- Pemilihan Format : Game android yang dikembangkan dalam bentuk apk, dimana hanya bisa dimainkan dan dijalankan lewat Handphone dengan sistem android

- Rancangan Awal Media Pembelajaran : menetapkan konsep dan desain seperti background, karakter pemain, dan icon tomboltombol.

- Penyusunan Tes : Tes pada pengembangan media pembelajaran berupa tes hasil belajar yang terdiri dari 6 latihan soal di setiap level pada game dan 5 soal isian singkat setelah penggunaan media.

3) Tahap Pengembangan

- Validasi dari para ahli : Validasi dilakukan oleh validator yang terdiri atas dua dosen Pendidikan Matematika dan satu guru SMPN 4 Jember.

- Uji Coba : Uji coba dilakukan untuk mengetahui kepraktisan dan keefektifan media pembelajaran yang dilakukan di SMPN 4 Jember pada kelas VIII sebanyak 31 siswa.

4) Tahap Penyebaran

Tahap ini dilaksanakan di seluruh kelas VIII SMP Negeri 4 Jember. Media pembelajaran dalam bentuk apk diserahkan kepada guru matematika masingmasing kelas.

Teknik pengumpulan data dalam penelitian ini menggunakan wawancara, tes, dan angket. Suatu media pembelajaran dikatakan layak digunakan jika memenuhi kategori valid, praktis, dan efektif. Validitas adalah suatu ukuran yang menunjukkan tingkat-tingkat kevalidan dan kesahihan suatu instrumen, untuk memenuhi kevalidan perlu tiga aspek yang diperlukan untuk penilaian oleh para ahli yaitu aspek format, aspek isi, dan aspek kebahasaan. Media pembelajaran dapat dikatakan praktis jika memberikan kemudahan kepada pengguna, intrumen yang digunakan pada kriteria ini adalah angket respon siswa yang diberikan kepada para siswa sebagai pengguna setelah menggunakan media pembelajaran. Efektivitas dipenuhi, jika hasil belajar siswa setelah mendapatkan pembelajaran menggunakan media pembelajaran komik matematika berbasis teknologi dapat memenuhi kriteria ketuntasan belajar yang ditunjukkan dari tes efektif jika $80 \%$ dari seluruh subjek uji coba memenuhi ketuntasan belajar.

\section{HASIL DAN PEMBAHASAN}

Penelitian pengembangan ini menghasilkan media yang valid, praktis dan efektif. Hasil penelitian ini diproses melalui tahapan-tahapan 4D yaitu, pendefinisian (Define), perancangan (Design), pengembangan (Develop), dan penyebaran (Disseminate) berikut:

a. pendefinisian (Define) 
pada tahap ini menetapkan tujuan pembuatan media pembelajaran matematika berupa game android dengan berbantuan software Construct 2 . Pertama mengkaji masalah yang terjadi yaitu ketidaktertarikan siswa pada media pembelajaran yang digunakan saat kegiatan belajar mengajar, serta adanya kemajuan teknologi dan informasi berdampak pada karakter siswa. Materi yang digunakan pada media ini yaitu pola bilangan. Siswa diberikan tugas meliputi latihan soal serta tes hasil belajar sebagai tolak ukur kemampuan siswa terhadap pemahaman materi yang diajarkan. Tujuan yang ingin dicapai dengan adanya media pembelajaran ini adalah menciptakan media pembelajaran yang dapat mempermudah proses pembelajaran, efisien, menyenangkan, mempermudah interaksi siswa dan guru serta dapat menarik minat belajar siswa.

b. perancangan (Design)

Pada tahap ini merupakan proses merancang media pembelajaran, sehingga dihasilkan draft 1 (media pembelajaran yang belum valid). Media pembelajaran yang dikembangkan dalam penelitian ini berupa aplikasi game edukasi android yang diberi nama GEMBIL (Game Edukasi Matematika materi Pola Bilangan) dalam bentuk apk, dimana hanya bisa dimainkan dan dijalankan lewat Handphone dengan sistem android. Rancangan awal media pembelajaran dapat dilihat pada Gambar 1.

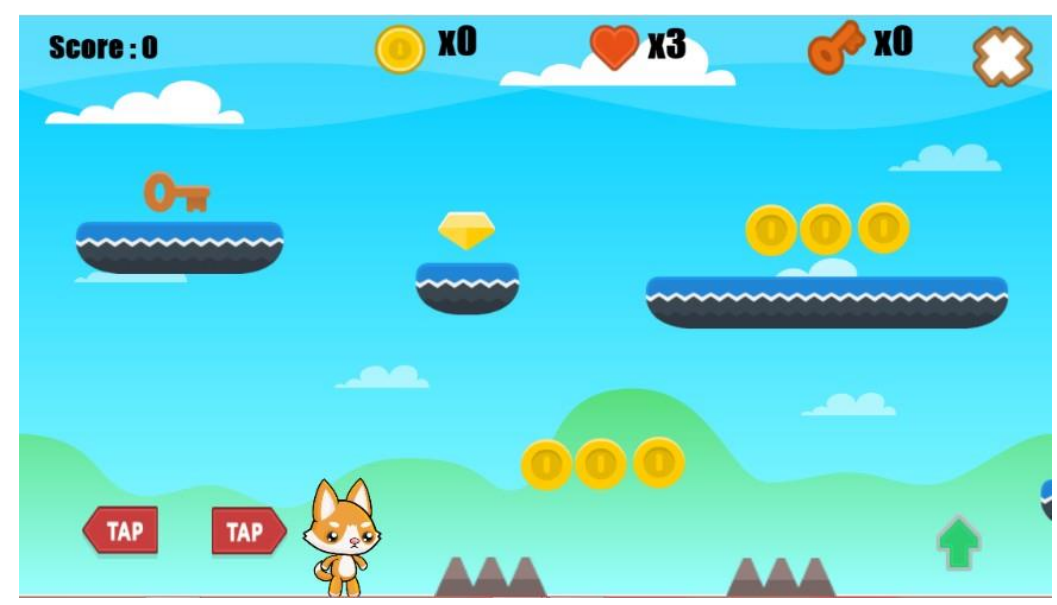

Gambar 1. Rancangan awal media

c. pengembangan (Develop)

Pada tahap ini validasi dari para ahli dilakukan oleh validator yang terdiri atas dua dosen Pendidikan Matematika dan satu guru SMPN 4 Jember. Serta uji coba dilakukan di SMPN 4 Jember pada kelas VIII sebanyak 30 siswa. Menurut (Khabibah, 2006), suatu material dikatakan berkualitas baik, jika memenuhi aspek-aspek kualitas yaitu: (1) validitas (validity), (2) kepraktisan (practically) dan (3) keefektifan (effectivenes). Berdasarkan hasil dari validasi media untuk media pembelajaran 
matematika berbasis game android berbantuan Software Construct 2 pada pola bilangan memperoleh nilai validitas sebesar 0,87. Sehingga dapat disimpulkan bahwa media pembelajaran ini valid dengan kategori interpretasi sangat tinggi dan telah memenuhi kevalidan. Hasil validasi media pembelajaran yang berada dalam kategori interpretasi sangat tinggi menunjukkan bahwa media pembelajaran ini praktis secara teoritis. Nilai dari validator dapat dilihat pada Gambar 2.

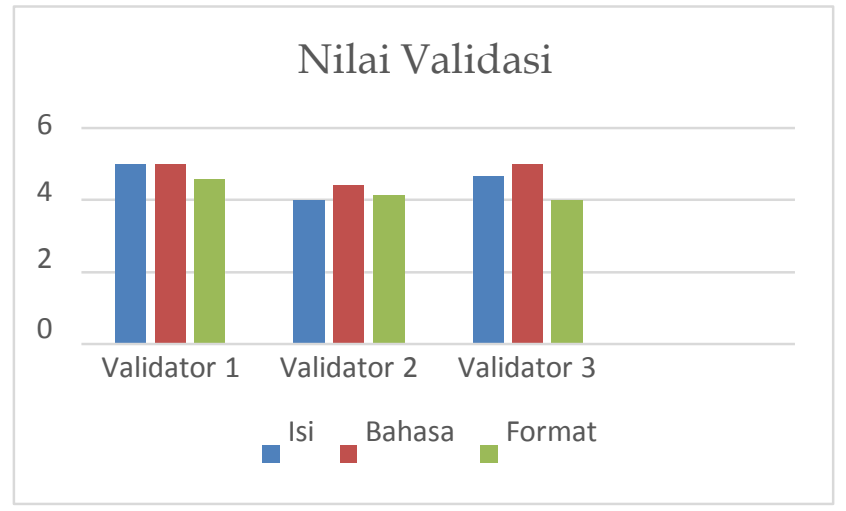

Gambar 2. Nilai Validasi

Praktis secara praktek dapat dilihat dari hasil analisis angket respon pengguna menunjukkan kategori baik atau sangat baik, maka pembelajaran matematika menggunakan media pembelajaran berupa game edukasi materi pola bilangan berbasis teknologi android dikatakan praktis secara praktek. Dari hasil analisis angket respon siswa, media pembelajaran game android telah dinyatakan praktis bagi siswa ditunjukkan dengan data angket respon pengguna menunjukkan presentase angket sebesar $86 \%$ sesuai kategori presentase angket pengguna media yang telah dimodifikasi dari (Hobri, 2010) menunjukkan bahwa siswa selama melaksanakan pembelajaran menggunakan game android merasa mudah, merasa senang, tidak bosan belajar dan termotivasi untuk belajar matematika.Hasil Angket siswa dapat dilihat pada Tabel 1.

\section{Tabel 1. Hasil Angket Siswa}

\begin{tabular}{|c|c|c|c|}
\hline No. & Kriteria & Rata-rata & Persentase \\
\hline 1. & $\begin{array}{l}\text { Kemudahan dalam mengoprasikan } \\
\text { media }\end{array}$ & 3,30 & $82,5 \%$ \\
\hline 2. & $\begin{array}{l}\text { Media mengalami kelancaran saat } \\
\text { dijalankan }\end{array}$ & 3,40 & $85 \%$ \\
\hline 3. & Pemahaman materi yang disajikan & 3,67 & $91,75 \%$ \\
\hline 4. & $\begin{array}{l}\text { Pemahaman permasalahan yang } \\
\text { terdapat dalam soal }\end{array}$ & v & u \\
\hline 5. & Bahasa yang digunakan jelas & 3,57 & $89,25 \%$ \\
\hline
\end{tabular}




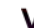

\begin{tabular}{clcc} 
6. & Pemilihan warna pada media sesuai & 3,33 & $83,25 \%$ \\
$\%$ & Jenis nurut yang digunakan mudan & 3,40 & $85 \%$ \\
dibaca & 3,60 & $90 \%$ \\
8. Ketertarikan dengan adanya media & 3,33 & $83,25 \%$ \\
10. Pemahaman materi lebih mudah & 3,40 & $85 \%$ \\
\hline & melalui bantuan media pembelajaran & $86 \%$ \\
\hline
\end{tabular}

Media pembelajaran game edukasi android ini dikatakan efektif jika memenuhi indikator keefektifan yang ditunjukkan dari rata-rata skor tes hasil siswa memenuhi ketuntasan klasikal, yaitu 80\% dari seluruh siswa mendapatkan skor lebih besar atau sama dengan Kriteria Ketuntasan Minimum (KKM) (Mulyasa, 2007) dan lebih dari 50\% siswa memberikan respon positif (berdasarkan angket) terhadap media pembelajaran yang di uji cobakan (Murtikusuma, 2019). Uji keefektifan dilakukan untuk mengetahui seberapa efektif media pembelajaran matematika berbasis game android berbantuan software Construct 2 yang telah dikembangkan. Berdasarkan hasil tes didapatkan presentase siswa yang mendapat nilai di atas KKM sebesar 90\% dan dikategorikan sangat baik. Jumlah siswa yang mendapat nilai lebih dari sama dengan 76 adalah 27 siswa. Pembelajaran matematika dengan menggunakan media pembelajaran matematika berbasis game android berbantuan software construct 2 terbukti efektif untuk meningkatkan motivasi dan prestasi belajar siswa terhadap materi yang sedang dipelajari. Hasil tes kemampuan siswa dapat dilihat pada Gambar 3.

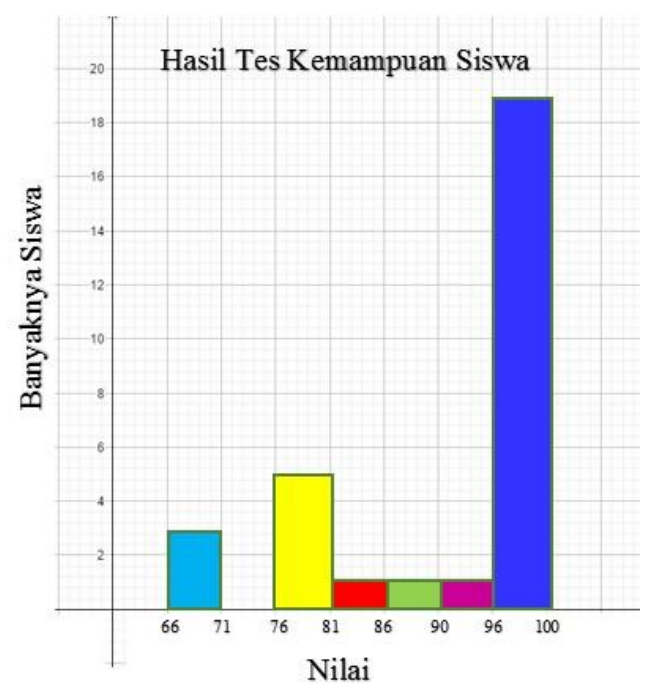

Gambar 3. Hasil Tes Kemampuan Siswa 
d. penyebaran (Disseminate)

Tahap penyebaran dalam penelitian ini hanya dilakukan di lingkungan sekolah penelitian, yaitu di SMP Negeri 4 Jember, khususnya kelas VIII. Aktivitas pembelajaran matematika memggunakan media game android dapat dilihat pada Gambar 4. Tahap penyebaran penelitian ini dimulai dengan memberikan apk kepada guru matematika kelas VIII untuk dijadikan bahan ajar siswa sebagai media pembelajaran dikelas yang lainnya.

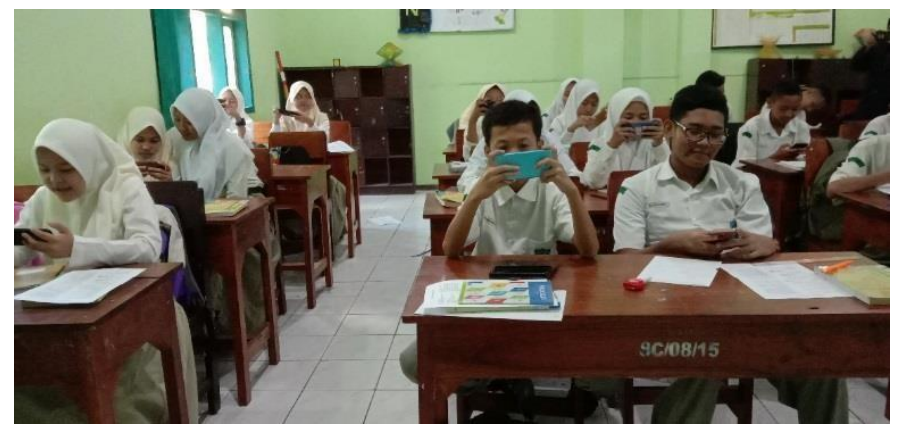

Gambar 4. Aktivitas Pembelajaran Matematika

Game android yang telah dikembangkan dalam penelitian ini memiliki keunggulan dalam penggunaan yaitu pengguna dapat menggunakan media pembelajaran dimanapun tanpa menggunakan jaringan internet sehingga lebih efisien. Hal serupa juga pernah dilakukan oleh (Wijaya, Fatahillah, \& Oktavianingtyas, 2018), dengan judul penelitian yaitu "Pengembangan Media Pembelajaran Matematika Berbasis Game Android Berbantuan software Construct 2 pada materi Segitiga" dan didapatkan hasil yaitu proses pengembangan pada penelitian ini menggunakan model Thiagarajan yang telah dimodifikasi dan terdiri dari tiga tahap, yaitu tahap pendefinisian, tahap perancangan, dan tahap pengembangan. Uji coba penelitian ini dilakukan kepada siswa kelas VII. Uji coba dilakukan untuk mengetahui kepraktisan dan keefektifan media pembelajaran yang kembangkan. Berdasarkan hasil analisis data tersebut, maka dapat diperoleh hasil bahwa media pembelajaran matematika berbasis game android pada materi segitiga telah memenuhi kriteria valid, praktis, dan efektif.

\section{PENUTUP}

Berdasarkan hasil dari validasi media untuk media pembelajaran matematika berbasis game android berbantuan Software Construct 2 pada pola bilangan memperoleh nilai validitas sebesar 0,87. Sehingga dapat disimpulkan bahwa media pembelajaran ini valid dengan kategori interpretasi sangat tinggi dan telah memenuhi kevalidan. Hasil validasi media pembelajaran yang berada dalam kategori interpretasi sangat tinggi menunjukkan bahwa media pembelajaran ini praktis secara teoritis 
Angket respon pengguna diberikan setelah siswa menggunakan media pembelajaran untuk media pembelajaran matematika berbasis game android berbantuan Software Construct 2 pada pola bilangan. Dari hasil analisis angket respon pengguna diperoleh presentase sebesar $86 \%$ dan termasuk dalam kategori baik. Sehingga dapat disimpukan bahwa media pembelajaran ini praktis secara praktek. Hal ini menunjukkan bahwa siswa selama melaksanakan pembelajaran menggunakan media pembelajaran matematika berbasis game android merasa mudah, merasa senang, tidak bosan belajar dan termotivasi untuk belajar matematika setelah menggunakan media pembelajaran yang telah dikembangkan ini. Siswa merasa antusias menggunakan media pembelajaran game android karena selama siswa melaksanakan pembelajaran di kelas, belum pernah mendapatkan pembelajaran game android edukasi. Data yang didapat melalui angket dan penilaian siswa membuktikan bahwa media pembelajaran praktis dan efisien untuk digunakan.

Kemudian dari hasil analisis tes hasil belajar siswa diperoleh nilai rata-rata sebesar 92,33 dan banyaknya siswa yang mendapat nilai lebih dari atau sama dengan kriteria ketuntasan minimal (KKM) adalah 27 siswa atau 90\% dengan rincian 27 siswa mendapatkan nilai 76 ke atas, 3 siswa lainnya mendaptkan rata-rata nilai kelas dibawah 76, dan seorang siswa tidak masuk dikarenakan sakit. Dari data analisis tes hasil belajar dapat disimpulkan bahwa media pembelajaran ini efektif.

Saran dari hasil penelitian ini yang dapat dikemukan oleh peneliti yaitu bagi peneliti yang mengembangkan penelitian sejenis sebaiknya dilakukan pengecekan terlebih dahulu komponen yang dibutuhkan dalam pelaksanaan seperti hp android tanpa low battery, kinerja hp android, dll serta media pembelajaran game android seperti ini hendaknya dikembangkan lebih luas ke jenjang atau tingkatan sekolah yang berbeda agar kemajuan teknologi dan informasi juga dapat diterapkan dalam pembelajaran sehingga siswa dapat antusias dan tertarik khususnya belajar pelajaran matematika.

\section{DAFTAR PUSTAKA}

Asmin. (2003). Implementasi Pembelajaran Matematika Realistik (PMR) dan Kendala yang Muncul di Lapangan (Versi Elektronik). Pendidikan Dan Kebudayaan, 2.

Daryanto. (2010). Media Pembelajaran. Yogyakarta: Gavamedia.

Hobri. (2010). Metode Penelitian Pengembangan (Aplikasi pada Penelitian Matematika). Jember: Pena Salsabila.

Idris, M. (2019). Peningkatan Kemampuan Pemahaman Matematis dan Self Regulated Learning Melalui Model Teams Games Tournament berbasis Kartu Trimino. 
Kevin, V. S. (2019). Perancangan Game Edukasi untuk Meningkatkan Minat dan Pemahaman Anak Usia 6-8 Tahun Terhadap Matematika Melalui Komunikasi Visual. UNIKA SOEGIJAPRANATA SEMARANG.

Khabibah, S. (2006). Pengembangan Model Pembelajaran Matematika dengan Soal Terbuka untuk Meningkatkan Kreatifitas Siswa Sekolah Dasar. Disertasi yang tidak dipublikasikan oleh Pasca Sarjana Unesa.

Khatimah, H., Johar, R., \& Taufik Fuandi Abidin. (2019). Upaya Guru Menggunakan Game dalam Pembelajaran Matematika. Peluang, 1, 13-21.

Mulyani, E. W. S. (2018). Dampak Pemanfaatan Aplikasi Android dalam Pembelajaran Bangun Ruan. Teknologi Pendidikan, 6.

Mulyasa, E. (2007). Standar Kompetensi dan Sertifikasi Guru. Bandung: Rosdakarya.

Murtikusuma, R. P. (2019). The development of interactive mathematics learning media based on schoology and visual basic through industrial revolution 4 . 0 The development of interactive mathematics learning media based on schoology and visual basic

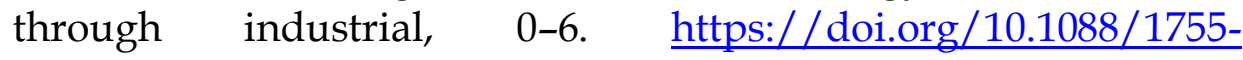
$1315 / 243 / 1 / 012137$

Putriani, D. (2017). Pengembangan Media Pembelajaran Berbasis Android dengan Program Construct 2 pada Materi Bangun Ruang Sisi Datar Untuk Siswa SMP Kelas 8. Pendidikan Matematika, 6(3).

Sari, D. P. (2019). Berbasis Mobile Learning Melalui Game Edukasi Laciku pada Materi Operasi Aljabar Sebagai Learning Exercise bagi Siswa. UIN Raden Intan Lampung.

Setiawani, S., Hobri, \& Wibowo, H. C. (2017). Proses Berpikir Siswa Autis dalam Menyelesaikan Soal Kontektual Dilihat dari Teori Suryabrata. Kadikma, 8(2), 41-50.

Setyosari, P. (2013). Metode Penelitian Pendidikan dan Pengembangan. Jakarta: Kencana.

Soedjadi, R. (2000). Kiat Pendidikan Matematika di Indonesia. Jakarta: Dirjen Dikti Depdiknas.

Tirri, K., Cho, S., Ahn, D., \& Campbell, J. R. (2017). Education for Creativity and Talent Development in the 21st Century. Education, 2017, 2-4.

Ulfa, M. K. (2018). Peningkatan Hasil Belajar Matematika Materi Bangun Ruang Melalui Metode Teams Games Tournament (TGT) dan Media Permainan Ular Tangga. Institut Agama Islam Negeri Salatiga.

Wahid, N. A., Fatahillah, A., \& Dafik. (2016). Pengembangan Media Pembelajaran Interaktif Online Berbantuan Software. Jurnal Edukasi, I,1.

Wijaya, H. T., Fatahillah, A., \& Oktavianingtyas, E. (2018). Pengembangan Media Pembelajaran Berbasis Game Android dalam Menghadapi Era Revolusi Industri 4 . 0 ( Development of 
E-155n 2656-5845 Pengembangan game android berbantuan software construct 2

P-|55n 2656-2286 pada pola bilangan

Learning Media Based on Android Game in Dealing With Industrial Revolution Era 4.0 ). 
